\title{
Comparing production-biomass ratios of benthos and suprabenthos in macrofaunal marine crustaceans
}

\author{
J .E. Cartes, T. Brey, J .C. Sorbe, and F. Maynou
}

\begin{abstract}
Using available data from the literature, we compared the production-biomass ratios $(P / B)$ between the suprabenthic (= hyperbenthic) and the benthic (infauna-epifauna) species within the group of the macrofaunal marine crustaceans. This data set consists of $91 P / B$ estimates (26 for suprabenthos and 65 for infauna-epifauna) for 49 different species. Suprabenthic crustacean $P / B$ was significantly higher than $P / B$ of benthic crustacean (post-hoc Scheffé test; one-way analysis of covariance, ANCOVA; $p<10^{-3}$ ) and also of other (noncrustacean) benthic invertebrate $\left(p<10^{-4}\right)$. Predictive multilinear regression (MLR) analysis for macrofaunal marine crustaceans showed $P / B$ to depend significantly on mean annual temperature $(T)$ and mean individual weight $(W)\left(R^{2}=0.367\right)$. Adding the variable swimming capacity increased goodness-of-fit to $R^{2}=0.528$. The higher $P / B$ of suprabenthic (= swimming) macrofauna in comparison with that of the benthic compartment seems to be related to the most apparent feature of the suprabenthos, its swimming capacity. The high $P / B$ s reported for suprabenthic species indicate how a nontrivial part of benthic production can be ignored if suprabenthos is not well sampled, therefore biasing the models of energy flow generated for trophic webs.
\end{abstract}

\begin{abstract}
Résumé : Les données de la littérature nous ont permis de comparer les rapports production-biomasse $(P / B)$ chez les espèces suprabenthiques (= hyperbenthiques) et endobenthiques-épibenthiques de la macrofaune carcinologique marine. Ces données comprennent 91 estimations du $P / B$ de 49 espèces (26 pour le suprabenthos et 65 pour l'endofauneépifaune). Les $P / B$ des crustacés suprabenthiques sont plus élevés que ceux des crustacés endo- et épibenthiques (test post-hoc de Scheffé ; analyse de covariance à un critère de classification, ANCOVA; $p<10^{-3}$ ) ainsi que ceux des autres invertébrés (non crustacés) benthiques $\left(p<10^{-4}\right)$. Une analyse de régression multilinéaire (MLR) prédictive révèle que le $P / B$ des crustacés de la macrofaune marine est significativement corrélé à la température annuelle moyenne $T$ et à la masse individuelle moyenne $W\left(R^{2}=0,367\right)$. La prise en compte de la capacité natatoire des espèces dans cette analyse améliore l'ajustement du modèle régressif aux données $\left(R^{2}=0,528\right)$. Les $P / B$ élevés des espèces suprabenthiques par comparaison aux espèces endo- et épibenthiques semblent donc être liés à leurs capacités natatoires, particularité qui caractérise le compartiment suprabenthique. De ce fait, une fraction non négligeable de la production benthique globale peut être ignorée si le suprabenthos est mal échantillonné, introduisant ainsi un biais dans les modèles de flux d'énergie générés par l'analyse des réseaux trophiques.
\end{abstract}

\section{Introduction}

Secondary production of many aquatic invertebrate populations has been analyzed by studies applying methods based on either growth and mortality of identifiable cohorts (e.g., Waters 1977; Benke 1984; Crisp 1984) or on the loss of biomass by size-frequency classes (Hynes-Hamilton and Coleman 1968; Hamilton 1969; Menzies 1980). In attempts to quantify energy flow through ecosystems, both freshwater and marine ecologists have constructed predictive empirical models to calculate benthic population production and $P / B$ (production-biomass ratio) from more easily obtained abiotic and population parameters. Usually these models are single regression (Robertson 1979; Banse and Mosher 1980; Edgar 1990) or multiple linear regression (e.g., Plante and Downing 1989; Morin and Bourassa 1992; Brey 1999), but more recently, alternative approaches (e.g., artificial neural network) have been adopted (Brey et al. 1996).

The biotic and abiotic parameters generally used in these models are body mass, biomass, temperature, and water depth (Brey 1990; Benke 1993; Tumbiolo and Downing 1994). Parameters related to taxonomy, life history, or functional trophic

Received 23 October 2001. Accepted 30 August 2002. Published on the NRC Research Press Web site at http://cjfas.nrc.ca on 11 October 2002.

$\mathrm{J} 16585$

J.E. Cartes $^{1}$ and F. Maynou. Institut de Ciències del Mar (CSIC), Passeig Marítim de La Barceloneta 37-49, 08003 Barcelona, Spain.

T. Brey. Alfred Wegener Institute for Polar and Marine Research, P.O. Box 120161, 27515 Bremerhaven, Germany.

J.C. Sorbe. Laboratoire d'Océanographie Biologique (UMR 5805, CNRS/UB1), 2 rue du Professeur Jolyet, 33120 Arcachon, France.

${ }^{1}$ Corresponding author (e-mail: jcartes@icm.csic.es). 
groups have been discussed (Benke 1993), but rarely incorporated as independent variables in models. When they have been applied, only broad taxonomic groups and general life strategies (sessile-motile, infauna-epifauna; see Brey 1999) have been considered.

Until recently, suprabenthic (= hyperbenthic) species were not included in regression models because they were not well represented in benthic samples taken with traditional endobenthic-epibenthic gear (cf. Huberdeau and Brunel 1982), i.e., grabs or box corers, which correctly estimate only the density of infauna or nonswimming epifauna (Buchanan and Warwick 1974; Sainte-Marie and Brunel 1985). Suprabenthic species (consisting of mysids, isopods, or amphipods) are characterized by their swimming capacity (see SainteMarie and Brunel 1985; Mees and Jones 1997). There is increasing evidence that the suprabenthos (= hyperbenthos) plays a key role in energy transfer in the benthic boundary layer (e.g., Sorbe 1981; Mees and Jones 1997; Cartes and Maynou 1998). High $P / B$ s have been reported for suprabenthic peracarids (San Vicente and Sorbe 1993, 1995; Cartes and Sorbe 1999) from coastal, shelf, and bathyal communities, leading to the question of whether suprabenthic species show generally higher $P / B$ s than infaunal species (Cartes and Sorbe 1999). Failure to address these presumably high $P / B$ s of suprabenthic species would imply ignoring a nontrivial part of the benthic production if suprabenthos is not sampled, resulting in biased models of energy flow in trophic webs.

In the present study, we review the available data on suprabenthic macrofaunal secondary production and $P / B$ and compare suprabenthic with benthic (infaunal and epifaunal) species productivity. New models to predict production and $P / B$ for marine macrobenthic crustaceans are generated including suprabenthic species. Our aim is not only to summarize the available data on suprabenthos production, but also to stimulate more interest for the study of this fauna as a key compartment in the functioning of trophic webs.

\section{Material and methods}

The species were classified as belonging to either the suprabenthic or the infaunal-epifaunal groups according to the gear with which they were collected: grabs or corers to sample benthos and sledges to sample suprabenthos. Both types of gear capture quite dissimilar fauna and they are complementary methods, as indicated by the different dominance of peracarid crustacean species captured with box corers and sledges (Sainte Marie and Brunel 1985; Elizalde 1994; J. Cartes, unpublished data). Suprabenthos is only correctly sampled using sledges because of its swimming capacity, which is the main distinctive feature of suprabenthos compared with benthos. Presently, because of the incomplete knowledge of the biology and ecology of most species, no biological criteria are available to separate benthic and suprabenthic species. The aim of this study was to test possible differences between benthic and suprabenthic species as a function of the biological variable $P / B$.

$P / B$ data of sublittoral suprabenthic and infaunalepifaunal (benthic) crustaceans were taken from our unpublished results and from the literature (Table 1). The selected species are included in the macrofaunal component and were captured or sieved (benthos) through mesh sizes of $0.5 \mathrm{~mm}$ (range: $0.3-1.0 \mathrm{~mm}$ ). Twelve of the $65 P / B \mathrm{~s}$ of benthos and four of the $26 P / B$ s of suprabenthos were obtained using mesh sizes $>0.5 \mathrm{~mm}$. Additional data on other benthic (noncrustacean) invertebrates were taken from the data compiled by Brey (1990). All $P / B$ data used in this study were computed by cohort-based (Waters 1977; Crisp 1984), growth rate based (Crisp 1984), or size-frequency methods (HynesHamilton and Coleman 1968; Hamilton 1969; Menzies 1980). The latter requires neither separation of cohorts nor knowledge of the exact growth function. Indirect estimations obtained either by multiplying $P / B$ and mean annual biomass estimations or as function of respiration (no field data) were not considered. For suprabenthic crustaceans, secondary production $(P)$ and $P / B$ have been estimated in previous studies (Cartes and Sorbe 1999; Cartes et al. 2000, 2001) using the size-frequency or Hynes-Hamilton method (Menzies 1980), where

$$
P=\left[\sum\left(d_{j}-d_{j+1}\right)\left(w_{j} w_{j+1}\right)^{0.5}\right] \cdot 12 / \mathrm{CPI}
$$

and $d_{j}$ and $w_{j}$ are the density and biomass of each size class, respectively. The cohort production interval (CPI, months) requires a basic knowledge of the life history of species. Other studies in suprabenthic (hyperbenthic, neritic) species also used methods based on the lost (or gained) biomass of cohorts (see Waters 1977; Crisp 1984; Gage 1992) distinguishable in size-frequency histograms. The $P / B$ and $P$ for Natatolana borealis was estimated using the weight-specific growth rate method (see Crisp 1984; Brey et al. 1990). The growth parameters were adopted from the study by KaïmMalka (1997) off Marseille, and the mean annual biomass was taken from our own unpublished data obtained from a seasonal sampling at bathyal depths off Barcelona (Cartes and Sorbe 1999).

Suprabenthic and benthic crustacean $P / B$ s were compared by analysis of covariance (ANCOVA) $(P / B$ vs. suprabenthic crustaceans - benthic crustaceans - other benthic species with mean body weight as covariate) and post-hoc Scheffé test. A multiple linear regression model (model $\mathrm{MLR}_{1}$ ) relating $P / B$ to mean body weight ( $W$, mg dry weight (DW)), mean annual temperature $\left(T,{ }^{\circ} \mathrm{C}\right)$, and water depth $(Z, \mathrm{~m})$ was established by forward stepwise multiple regression using the complete data set (91 cases). Additionally, a model $\mathrm{MLR}_{2}$ was constructed using the qualitative variable swimming capacity $S_{\text {cap }}(0,1)$ to check for significant differences between benthic and suprabenthic species. Species captured with grabs or corers are considered to have no swimming capacity (0) vs. species captured with sledges (1). All MLR models were generated using the software Statistica 4.5. All mass units were converted to mg DW using conversion factors from the original data source or from the literature (references in Brey 1990, 1999). All quantitative variables except temperature (Plante and Downing 1989) were logtransformed to linearize the relations and reduce heteroscedasticity.

Various previously published empirical models were tested for suitability in estimating $P / B$ of suprabenthic crustaceans. Seven MLR models were tested, two for marine benthic invertebrates (Brey 1990; Tumbiolo and Downing 1994), four for freshwater species (Plante and Downing 1989; Morin and Bourassa 1992; Benke 1993), and the aquatic inverte- 


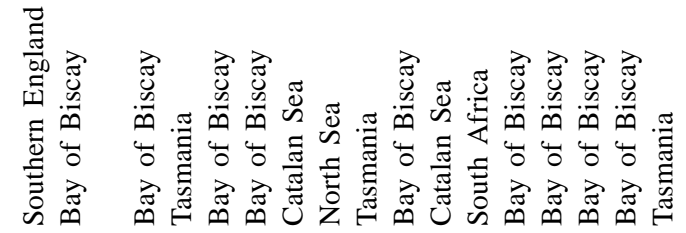

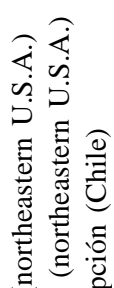

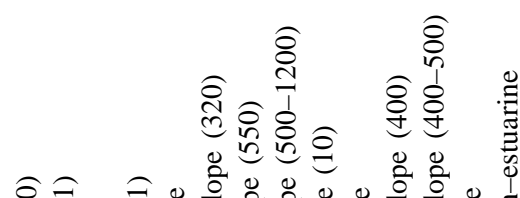

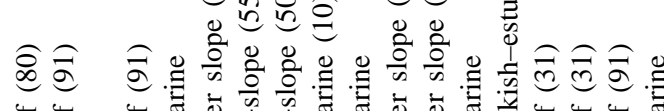

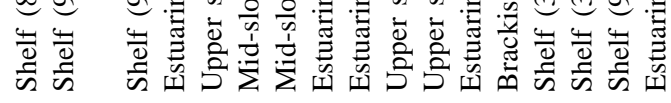

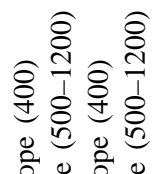

Iิ

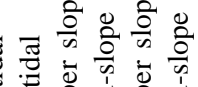

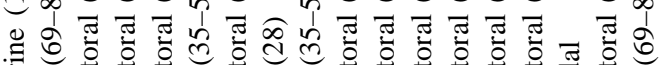

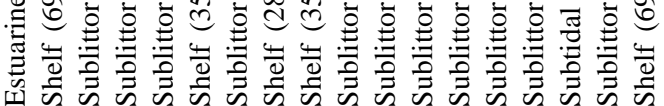

ஃ

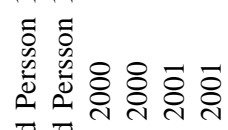
च ส बं नं 

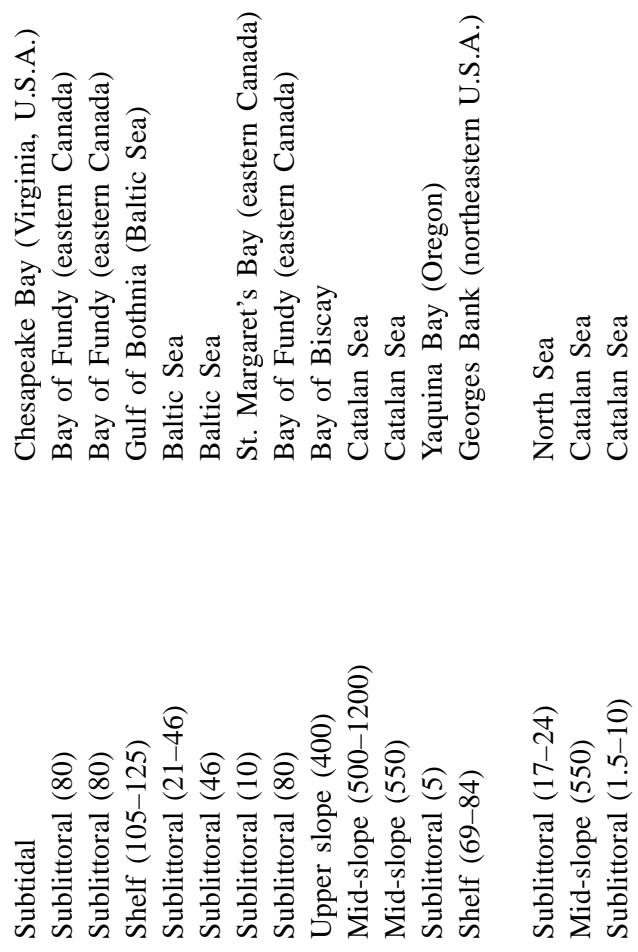

brate model of Brey (1999) (Table 2). The latter model also considers habitat, living mode, and taxon as qualitative $(0,1)$ variables. From freshwater studies, we adopted the models developed by Benke (1993; both the general and the crustacean models) and Morin and Bourassa (1992) for stream (running-water) organisms and the model by Plante and Downing (1989) for lake (lentic-water) organisms. Additionally, the artificial neural network (ANN) model published by Brey et al. (1996) was tested. The main advantage of this method is that a priori assumptions about the relationships between independent and dependent variables, as required for the MLR models, are not necessary, although these relationships cannot be expressed in traditional mathematical terms by using ANN (see Brey et al. (1996) for more detailed explanation of ANN methods applied to production studies). The accuracy and the precision of the models compared with the observed (field) data were determined by calculating the average residuals of each model and their respective variances. For this comparison, we considered the data of the 13 bathyal suprabenthic peracarid populations for the southeast Bay of Biscay (off Arcachon) and the Catalan Sea (off Barcelona) (see Table 1).

Besides the parameters included in these MLRs, other variables may affect $P / B$. However, the available data were insufficient to allow their entry as independent (quantitative) variables into MLRs. A preliminary analysis of the effect of these variables on $P / B$ can be carried out by examining the correlation between these and the MLR residuals (see Plante and Downing 1989). For this purpose, we examined the correlation between $P / B$ residuals of the $\mathrm{MLR}_{1}$ model (constructed based on quantitative variables only) and the following variables: $(i)$ the swimming coefficient $K_{t}$, which is deduced from the distribution of fauna at different distances above the sediment-water interface and is related to the swimming capacity $S_{\text {cap }}$ of species (cf. Sainte-Marie and Brunel 1985; Cartes 1998); (ii) the trophic diversity $\left(H^{\prime}\right.$; Shannon-Wiener index) calculated on the diet of each species (see Cartes et al. 2001); and (iii) the organic matter content $(\% \mathrm{OM})$ of the species. In the same way, we calculated the correlation between $P / B$ values and the cited functional (or trophic) variables, not included in the models, using the nonparametric Spearman correlation coefficient. The number of observations for the variables considered here ranged from $20\left(H^{\prime}\right)$ to $78\left(K_{t}\right)$.

\section{Results}

\section{The database}

Our data set consists of 91 cases, including 49 different crustacean macrobenthic species ( 2 decapods, 13 mysids, 4 isopods, 26 amphipods, 3 cumaceans, and 2 leptostracans). Twenty-six populations ( 21 species) are suprabenthic, whereas 65 populations ( 28 species) belong to the infauna-epifauna. The data set contains marine species inhabiting shallow subtidal $(0-0.5 \mathrm{~m})$ to deep bathyal (to $1852 \mathrm{~m}$ ) environments in subpolar-temperate regions $\left(40^{\circ}-60^{\circ} \mathrm{N}\right.$ latitude), covering a temperature range from 0.4 to $21.6^{\circ} \mathrm{C}$, although most data were from subpolar-temperate regions with mean annual $T$ ranging from 6 to $13^{\circ} \mathrm{C}$. Freshwater beach and intertidal species were not considered. Mean annual biomass ranged from 
Table 2. Multiple linear regression (MLR) models adopted to estimate $P / B$ (production-biomass ratio) for our suprabenthic species.

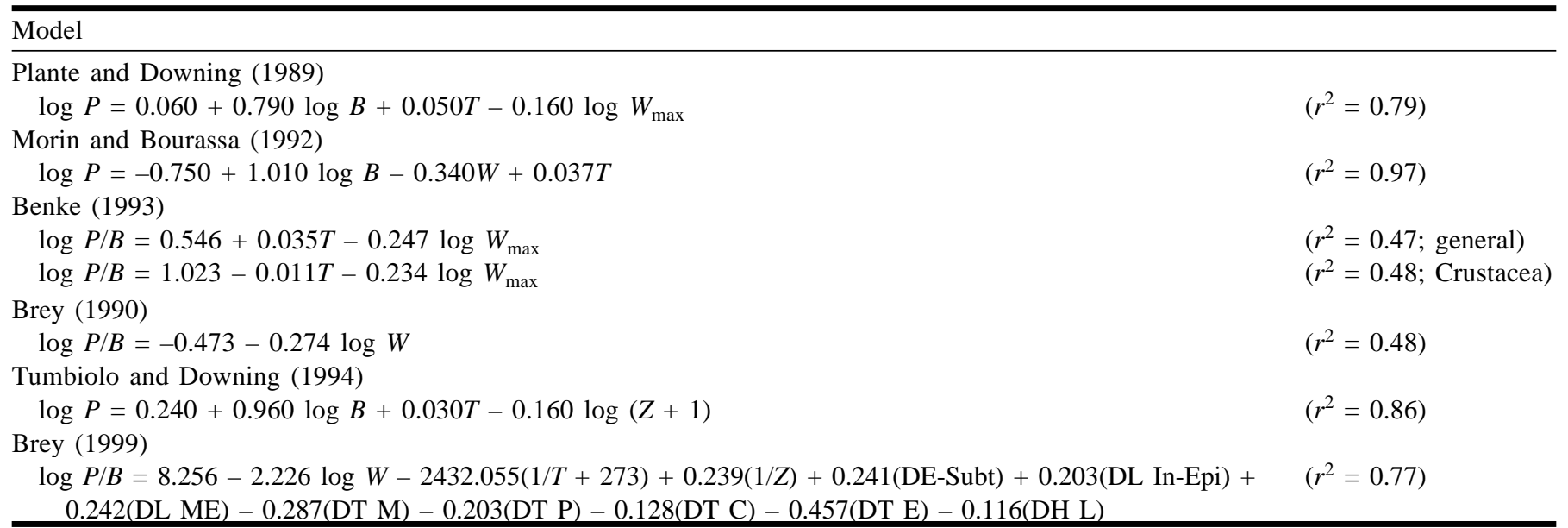

Note: $B$, mean annual biomass; $W$, mean individual weight; $W_{\max }$, maximum individual weight; $T$, mean annual temperature $\left({ }^{\circ} \mathrm{C}\right) ; Z$, depth $(\mathrm{m})$. The following variables from Brey's (1999) model are qualitative $(0,1)$ variables: DE-Subt, subtidal species; DL In-Epi, infaunal-epifaunal species; DL ME, motile fauna; DT M, Mollusca; DT P, Polychaeta; DT C, Crustacea; DT E, Echinodermata; DH L, lake habitat.

0.024 to $42600 \mathrm{mg} \mathrm{DW} \cdot \mathrm{m}^{-2}$, whereas mean individual weight ranged from 0.032 to $180.6 \mathrm{mg} \mathrm{DW} \cdot$ individual $^{-1}$.

A previous (one-tailed) $t$ test showed no significant differences between the $\log P / B$ of species sampled using different mesh sizes (mesh size $>0.5 \mathrm{~mm}$ and $\leq 0.5 \mathrm{~mm}$ ), both for benthos $(t=-0.404 ; p=0.34)$ and suprabenthos $(t=0.106$; $p=0.46)$. Furthermore, the mesh size was not an explanatory variable of $P / B$ when it was incorporated as an independent variable into the multilinear regression models (see below).

\section{Production-biomass ratios $(P / B$ s $)$}

$P / B$ s of suprabenthic and benthic (infaunal-epifaunal) crustaceans, as well as other benthic invertebrates, are shown as a function of mean weight $(W)$ (Fig. 1). An analysis of covariance (one-way ANCOVA, with post-hoc Scheffé test) using suprabenthic and benthic crustaceans, and other invertebrates as factors and $\log W$ as covariate, showed that mean $\log P / B$ of suprabenthic crustaceans $(0.744 \pm 0.285 ; n=26)$ was significantly higher than $P / B$ of benthic crustaceans $(0.466 \pm 0.329$; $\left.n=65 ; p<10^{-3}\right)$ and other invertebrates $(-0.034 \pm 0.326 ; n=$ $\left.28 ; p<10^{-4}\right)$. $\log P / B$ of benthic crustaceans was also significantly higher $\left(p<10^{-4}\right)$ than $\log P / B$ of other invertebrates. Slopes of the relation between $P / B$ and mean weight did not differ significantly among the three groups $(F=0.092 ; p=$ 0.912). One-way analysis of variance (ANOVA) and post-hoc Scheffé test detected significant differences in $\log W$ between suprabenthic crustaceans and other invertebrates $\left(p<10^{-8}\right)$, as well as between benthic crustaceans and other invertebrates $\left(p<10^{-11}\right)$, whereas no significant differences in $\log W$ between suprabenthic and infaunal crustaceans $(p=0.99)$ were found. Hence, $P / B$ comparisons are particularly reliable between suprabenthic and benthic crustaceans, whereas species of the category other invertebrates had higher mean body mass, which implies lower $P / B$.

\section{Multiple linear regression models}

Two MLR $P / B$ models were obtained for macrobenthic crustaceans (Table 3). In model $\operatorname{MLR}_{1}(1), P / B$ is signifi-
Fig. 1. $\log P / B$ (production-biomass ratio) vs. $\log$ mean body mass (dry weight, DW): suprabenthic crustaceans ( ) infaunalepifaunal crustaceans $(\bigcirc)$; other marine invertebrates $(\star)$ (derived from Brey 1990).

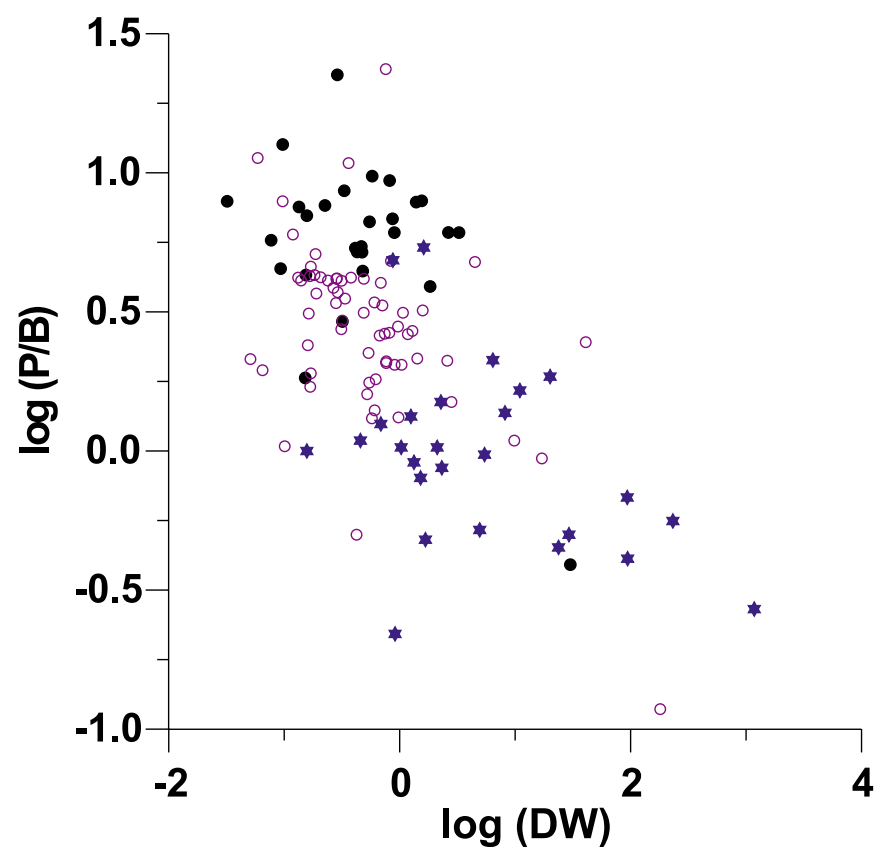

cantly correlated with environmental temperature $(T)$ and mean individual body mass $(W)$. The fitted equations (Table 3) showed that this model explains $36.7 \%$ of the variability in log $P / B$. Model $\mathrm{MLR}_{2}$ (2) included the qualitative variable $S_{\text {cap }}$ as an additional independent variable. $P / B$ was significantly correlated with $T, W, S_{\text {cap }}$, and $Z$, and the goodness-of-fit increased to $R^{2}=0.528$. In this second model, $S_{\text {cap }}$ accounted for $10.4 \%$ of the variability $(19.7 \%$ of the variance explained by $\mathrm{MLR}_{2}$ ), and $Z$ accounted for $5.7 \%$ of the total variability. The tolerance, which indicates the existing correlation between pairs of independent variables, was between 0.954 and 0.962 in $\mathrm{MLR}_{1}$ and between 0.657 and 0.927 in $\mathrm{MLR}_{2}$. 
Table 3. Characteristics of the multiple linear regression (MLR) models constructed to predict $P / B$.

\begin{tabular}{llll}
\hline Model & $n$ & $r^{2}$ & $p$ \\
\hline (1) $\log P / B=0.103+0.036 T-0.186 \log W$ & 91 & 0.367 & $<10^{-6}$ \\
$\left(\right.$ (2) $\log P / B=0.349-0.203 \log W+0.020 T+0.362 S_{\text {cap }}-0.119 \log Z$ & 91 & 0.528 & $<10^{-6}$ \\
$\log P=0.155+0.985 \log B-0.269 \log W+0.028 T$ & 91 & 0.965 & $<10^{-6}$ \\
\hline
\end{tabular}

Note: Mean individual weight $(W)$, depth $(Z$, pressure), and mean annual temperature $(T)$ were the considered independent variables. $S_{\text {cap }}$, swimming capacity, is a qualitative $(0,1)$ variable; $p=<0.05$ for all the independent variables. A model to predict production $(P)$ based on the same data set also included.

Table 4. Correlations between the residuals of $P / B$ model $\mathrm{MLR}_{1}$ (see Table 3) obtained for macrobenthic crustaceans and some trophic or functional variables.

\begin{tabular}{llll}
\hline Variables & Pearson $r$ (residuals) & Spearman's & $n$ \\
\hline$K_{t}$ & $0.258 *$ & $0.493 *$ & 78 \\
$\% \mathrm{OM}$ & $0.287 \mathrm{~ns}$ & $0.231 \mathrm{~ns}$ & 30 \\
$H_{\mathrm{T}}$ & $0.404 \mathrm{~ns}$ & $0.367 \mathrm{~ns}$ & 20 \\
\hline
\end{tabular}

Note: $K_{t}$, swimming coefficients; \%OM, organic matter content $(\%)$; $H_{\mathrm{T}}$, trophic diversity. Correlations using the nonparametric Spearman's coefficients between $P / B$ from the original field data and the same variables have been also included. *, $p<0.05$; ns, nonsignificant.

Therefore, dependence (redundancy) between pairs of independent variables was generally low.

A $P$ model was also constructed on the same database $(n=91)$. In this model, $P$ for macrobenthic crustaceans was significantly correlated with the mean annual biomass ( $B ; \mathrm{mg} \mathrm{DW} \cdot \mathrm{m}^{-2}$ ), $W$, and $T$ (Table 3 ). The goodness-of-fit was $R^{2}=0.965$

Analysis of residuals of $\mathrm{MLR}_{1}$ (excluding $S_{\text {cap }}$ as a variable) gave a positive correlation between $P / B$ residuals and $K_{t}$ of the species. Spearman coefficients gave parallel significant results (Table 4 ), with $K_{t}$ being positively correlated with $P / B$.

The empirical models tested here fall into three categories (Fig. 2): (i) three models, those of Brey (1990) and Tumbiolo and Downing (1994) and the ANN model of Brey et al. (1996), overestimated size-frequency method (SFM) results, with $\log$ mean residuals around +0.4 ; (ii) the freshwater models of Plante and Downing (1989), Morin and Bourassa (1992), and Benke (1993; both the general and the crustacean models) underestimated SFM results with log mean residuals distributed between -0.2 and -0.7 ; and (iii) the aquatic model of Brey (1999). Finally, MLR 2 gave residuals very close to zero in comparison with the SFM field data. Residuals of all models of group $i$ and those of the freshwater models of Plante and Downing (1989) and Benke (1993; both models) were significantly (a posteriori $t$ tests; $p<0.05)$ different from zero. Models of group $i$ overestimated suprabenthic $P / B$, whereas the freshwater models of Plante and Downing (1989) and Benke (1993; both models) underestimated suprabenthic $P / B$. In contrast, the model by Morin and Bourassa (1992), the aquatic model of Brey (1999), and $\mathrm{MLR}_{2}$ did not differ significantly from field $P / B$ calculations (Table 5). One-tailed $F$ tests were used to compare the pairwise variances between models. The results of these comparisons were not significant for most cases (Table 5), but they were significant for some of the comparisons involving the Plante-Downing model. Among the published models, the best overall fit to suprabenthos
$P / B$ was obtained by the model of Brey (1999; which is not significantly different from $0, p=0.96$; $t$ test), which incorporates the motility of benthos (sessile or nonsessile organisms) as an independent variable.

\section{Discussion}

$P / B$ is a standardized measure allowing comparisons between species having different individual biomass (Plante and Downing 1989). Our $P / B$ values obtained for suprabenthos (= swimming) macrofauna are generally higher than those obtained for infauna-epifauna within the group of the macrobenthic crustaceans. The method used to estimate $P / B$ for suprabenthos was mainly the size-frequency method (SFM), because it is not possible in multivoltine species to follow the growth of cohorts. Generally, cohort-based methods, as well as growth rate based methods, of production calculation are more accurate than the size-frequency method, because the latter makes quite simple assumptions about individual growth (linear) and age (cohort production interval, i.e., maximum lifespan only) (see Morin et al. 1987; Benke 1993; Mees et al. 1994). The bias involved in the SFM depends mainly on the shape of the growth curve: the more linear the curve, the better the SFM estimate of $P / B$. The $P / B$ of most suprabenthic species used in this study was computed by SFM, whereas all three approaches were used to compute $P / B$ of benthic species. Hence, a possible systematic bias could be introduced. Simultaneous use of SFM and cohort-based methods in stream benthos production studies, however, showed that $(i)$ differences between $P / B$ estimated by these methods were generally less than 10-30\% and (ii) SFM estimates were not consistently higher than cohort-based estimates (Benke 1993). Similar results were also reported in estuarine mysids (Mees et al. 1994). In the case of Neomysis integer, SFM resulted in values very similar to those obtained with cohort methods when it is possible to apply to cohorts separately (Mees et al. 1994), a consequence of strong differences in the life history of each cohort. Our suprabenthic data contain a number of bathyal species with generations having a similar life span (Cartes and Sorbe 1999; Cartes et al. 2000). Therefore, deep species probably better match the assumptions of the size-frequency method evidenced by Mees et al. (1994). Likewise, using the data that form the basis of the Brey (1999) model, no significant effects of the method on $P / B$ estimations could be detected (T. Brey, unpublished data).

Our $\mathrm{MLR}_{1}$ to estimate $P / B$ for small macrobenthic crustaceans had $R^{2}=0.367$, at the lower end of the range of variance explained by previous $P / B$ models, both for marine and freshwater organisms. Noting this low $R^{2}$ for $P / B$ models, it has been postulated that other factors besides temperature 
Fig. 2. Residuals (field data - models data) of $\log P / B$ (production-biomass ratio, \pm standard error) between the observed (field) data and a collection of empirical models for 13 bathyal suprabenthic peracarids for the southeast Bay of Biscay (off Arcachon) and the Catalan Sea (off Barcelona). Field values were obtained applying the size-frequency method (SFM). A total of seven empiric multiregression models and the artificial neural network (ANN) model by Brey et al. (1996) were used to estimate $P / B$ for the 13 selected species. MLR, multiple linear regression.

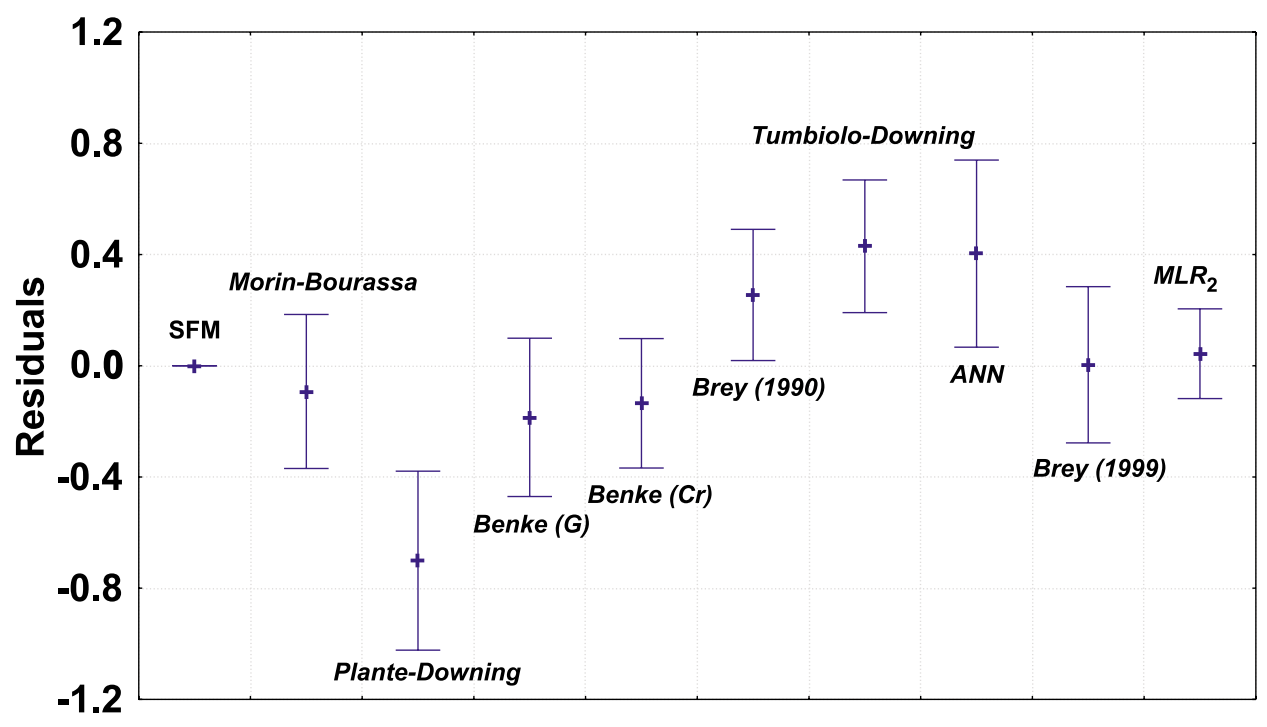

MLR/ANN models

Table 5. Results of $t$ tests between the residuals of $P / B$ (production-biomass ratio) obtained from field data (SFM, sizefrequency method) and those obtained after applying multiple linear regression (MLR) and artificial neural network (ANN) models.

\begin{tabular}{ll}
\hline Models & $p$ \\
\hline MLR & \\
Morin-Bourassa & $0.239 \mathrm{~ns}$ \\
Plante-Downing & $10^{-8}$ \\
Benke (general) & 0.027 \\
Benke (Crustacea) & 0.047 \\
Brey (1990) & $10^{-4}$ \\
Tumbiolo-Downing & $10^{-6}$ \\
Brey (1999) & $0.964 \mathrm{~ns}$ \\
MLR (present study) & $0.999 \mathrm{~ns}$ \\
ANN & $10^{-4}$ \\
\hline
\end{tabular}

Note: The data set consisted in 13 suprabenthic peracarids from bathyal depths of the Bay of Biscay and the Catalan Sea. ns, residuals are not significantly different from zero.

and individual mass may strongly affect $P / B$ (Benke 1993). After incorporating some variables implying habits (i.e., motility, swimming capacity) and habitat of species (Brey 1999; present study), higher predictive precision in $P / B$ models can be reached $(77.2 \%$ of variance, Brey $1999 ; 52.8 \%$, present study). Therefore, swimming capacity, or in a wider context, variables related to the motility of species are among the remaining factors significantly affecting $P / B$.

A variety of biological and (or) ecological variables may explain the higher $P / B$ reported for suprabenthic crustaceans in comparison with benthic species. Thus, a higher number and (or) smaller size of eggs have generally been reported for epifaunal amphipods than for infaunal ones (Nelson 1980; Van Dolah and Bird 1980). This trend has been related to the $r$ and $K$ strategies in terms of species mortality, although the influence of phylogenetic aspects has also been discussed (Fenwick 1984). Despite their interest, data on fecundity were very scarce for the species included in our $P / B$ data set, particularly for suprabenthic crustaceans; therefore, fecundity could not be incorporated into our models. Thus, based on our database, the major difference between benthic and suprabenthic groups is related to the higher $S_{\text {cap }}$ of suprabenthic species. The addition of $S_{\text {cap }}$ as a new qualitative $(0$, 1) variable to $P / B$ MLR models increased the goodness-offit from $R^{2}=0.367$ to $R^{2}=0.528$. $S_{\text {cap }}$ also accumulated an important part $(19.7 \%)$ of the explained variance. Likewise, a significant correlation between residuals of the $P / B \mathrm{MLR}_{1}$ and $K_{t}$ was also found. $K_{t}$ is deduced from the distribution of fauna at different distances above the sediment-water interface (cf. Sainte-Marie and Brunel 1985; Cartes 1998) and can be considered a continuous variable related to the swimming capacity of the species. Also, as indicated by our results, among the published empirical models, the model of Brey (1999), which includes the parameter motility as an independent variable, showed the best fit, further suggesting that high $P / B$ among suprabenthos may depend on their swimming capacity.

Swimming capacity itself may be correlated not only to different biological variables (e.g., fecundity), but also to ecological variables including the trophic level (TL) of the species. Among bathyal suprabenthos, filter feeders and scavengers-predators such as mysids (i.e., Boreomysis arctica) or lysianassid and eusirid amphipods show the highest $K_{t}$ as well as the highest $P / B$. On the other hand, macrobenthic crustaceans collected with grabs are consid- 
ered to be mostly deposit feeders, which probably consume more refractary food with lower nutritional value. This relation between trophic level and $P / B$ has been discussed by Benke (1993) for stream benthos, where shredders consuming low nutritional food have lower $P / B$ than filter feeders or (small) predators. Nevertheless, we could not detect any significant relation between $P / B$ and the only trophic variable here considered, the trophic diversity $\left(H^{\prime}\right)$, likely because $H^{\prime}$ is not necessarily a good indicator of the trophic level of species or because of the low number of available $H^{\prime}$ data (only 20). Although it is generally possible to estimate TL with precision for macrophagous taxa such as fish (see Pauly et al. 1998), it is very difficult to obtain detailed data on the diet and TL for small (microphagous) marine macrofauna.

Published MLR models based on marine infaunal-epifaunal benthos (collected with grabs or corers) always underestimated $P / B$ of our suprabenthic species, further suggesting different patterns in the life history of each compartment (e.g., differences in the $K$ and $r$ strategies) depending of the dynamics of the aquatic ecosystems that they inhabit. Besides the models incorporating the swimming capacity as independent variable, the freshwater model by Morin and Bourassa (1992) overall showed good estimations of $P / B$ for suprabenthic marine crustaceans, as has been reported in previous studies (San Vicente and Sorbe 1993; Cartes and Sorbe 1999). However, the freshwater model by Plante and Downing (1989) highly overestimated $P / B$ for our suprabenthic species. This bias may be attributable to the low individual mass of organisms included in this model (e.g., size magnitude of rotifers two orders below size of the species in our data base), although other variables (e.g., species habitat, food-source exploited) cannot be excluded. Freshwater MLR models refer either to stream (running-water) or to lake (lentic-water) species. Although stream models (Morin and Bourassa 1992; Benke 1993) are based on benthos, lake models are constructed combining planktonic and benthic data (Plante and Downing 1989). According to the results reported in marine environments, where zooplanktonic taxa (e.g., euphausiids or hyperiid amphipods) regularly have higher $P / B$ (Lindley 1982; Mauchline 1985) than benthic crustaceans, Plante and Downing (1989) also recorded higher production for zooplankton than for benthos populations in lakes. These authors explained this higher production of zooplankton by the influence of colder temperatures on production in lake bottoms occupied by benthos, whereas possible influence of the dynamics of aquatic ecosystems on the life history of organisms was not discussed. The inclusion of planktonic organisms in the Plante and Downing (1989) model, presumably from warmer and more productive waters than those in our data set, could also explain the high overestimation of $P / B$ s from our field data.

In conclusion, many factors could account for the fact that suprabenthic species generally have higher $P / B$ values than benthos (infauna-epifauna) within the group of macrobenthic crustaceans. Although high $P / B$ seems related to the swimming capacity of this interface fauna, this variable may correlate with other biological or ecological variables that should be further studied before they can be fully considered in numerical models. Improvements in the quality of these models should contribute to improve both benthic production estimates and general models of energy flow in trophic webs.

\section{Acknowledgements}

The present study was supported by the projects MAR90/757 and AMB93/0283 funded by the "Consejo Superior de Investigaciones Científicas" (Government of Spain) and by CICYT (Comisión Interministerial de Ciencia y Tecnología (Ministry of Research and Science)). The French program SUPRABATH was partially supported by CIRMAT-INSU (Oceanographic Cruises) and by the France JGOFS/Ecomarge Project. The first author benefitted from a contract from the Ramón y Cajal Call 2001 (MCYT). The authors also benefitted from Integrated Action HF-1997-0092 France-Spain. Our thanks go to Dr. A. Benke (University of Alabama), who revised an early version of the manuscript, and to Dr. A. Morin, who revised the paper.

\section{References}

Andersin, A.B., Lassig, J., and Sandler, H. 1984. On the biology and production of Pontoporeia affinis Lindstr. in the Gulf of Bothnia. Limnologica, 15: 395-401.

Banse, K., and Mosher, S. 1980. Adult body mass and annual production/biomass relationships of field populations. Ecol. Monogr. 50: 355-379.

Benke, A. 1984. Secondary production of aquatic insects. In The ecology of aquatic insects. Edited by V.H. Resh and D.M. Rosenberg. Praeger Publishers, New York. pp. 289-322.

Benke, A. 1993. Concepts and patterns of invertebrate production in running waters. Verh. Int. Verein. Limnol. 25: 15-38.

Brey, T. 1990. Estimating productivity of macrobenthic invertebrates from biomass and mean individual weight. Meeresforschung, 32: 329-343.

Brey, T. 1999. A collection of empirical relations for use in ecological modelling. NAGA ICLARM Quart. 22: 24-28.

Brey, T., Arntz, W.E., Pauly, D., and Rumohr, H. 1990. Arctica (Cyprina) islandica in Kiel Bay (Western Baltic): growth, production and ecological significance. J. Exp. Mar. Biol. Ecol. 136: $217-235$.

Brey, T., Jarre-Teichmann, A., and Borlich, O. 1996. Artificial neural network versus multiple linear regression: predicting $P / B$ ratios from empirical data. Mar. Ecol. Prog. Ser. 140: 251-256.

Buchanan, J.B., and Warwick, R.M. 1974. An estimate of benthic macrofaunal production in the offshore mud of the Northumberland coast. J. Mar. Biol. Assoc. U.K. 54: 197-222.

Carrasco, F.D., and Arcos, D.F. 1984. Life history and production of the sublittoral amphipod Ampelisca araucana. Mar. Ecol. Prog. Ser. 14: 245-252.

Cartes, J.E. 1998. Dynamics of the bathyal Benthic Boundary Layer in the north-western Mediterranean: depth and temporal variations and their possible connections within deep-sea trophic webs. Prog. Oceanogr. 41: 111-139.

Cartes, J.E., and Maynou, F. 1998. Food consumption by bathyal decapod crustacean assemblages in the western Mediterranean: an approach to predatory impact and to a food consumption food supply balance in a deep-water food web. Mar. Ecol. Prog. Ser. 171: 233-246.

Cartes, J.E., and Sorbe, J.C. 1999. Estimating secondary production in bathyal suprabenthic peracarid crustaceans from the Catalan 
Sea slope (western Mediterranean; 391-1255 m). J. Exp. Mar. Biol. Ecol. 239: 195-210.

Cartes, J.E., Elizalde, M., and Sorbe, J.C. 2000. Contrasting lifehistories and secondary production by Munnopsurus atlanticus from two deep-water areas of the NE Atlantic and the W Mediterranean. Mar. Biol. 136: 881-890.

Cartes, J.E., Elizalde, M., and Sorbe, J.C. 2001. Contrasting lifehistories, secondary production, and trophic structure of Peracarid assemblages of the bathyal suprabenthos from the Bay of Biscay (NE Atlantic) and the Catalan Sea (NW Mediterranean). DeepSea Res. 48: 2209-2232.

Collie, J.S. 1985. Life history and production of three amphipod species on Georges Bank. Mar. Ecol. Prog. Ser. 22: 229-238.

Corbera, J., San Vicente, C., and Sorbe, J.C. 2000. Life history and production of the cumacean Cumopsis goodsiri in Creixell Beach (Catalan Coast). J. Mar. Biol. Assoc. U.K. 80: 271-282.

Crisp, D.J. 1984. Energy flow measurements. In Methods for the study of marine benthos. Edited by N.A. Holme and A.D. McIntyre. Blackwell Scientific Publications, Oxford. IPB Handbook No. 16. pp. 197-279.

Dauvin, J.C. 1984. Dynamique d'ecosystemes macrobenthiques des fonds sedimentaires de la Baie de Morlaix et leur perturbation per les hydrocarbures de l'Amoco Cadiz. Thèse d'état, Université de Pierre et Marie Curie - Paris VI.

Dauvin, J.C. 1988a. Biologie, dynamique, et production de populations de crustacés amphipodes de la Manche occidentale. 1. Ampelisca tenuicornis (Lilljeborg). J. Exp. Mar. Biol. Ecol. 118: 55-84.

Dauvin, J.C. 1988b. Biologie, dynamique, et production de populations de crustacés amphipodes de la Manche occidentale. 1. Ampelisca brevicornis (Costa). J. Exp. Mar. Biol. Ecol. 119: 213-233.

Dauvin, J.C. 1988c. Biologie, dynamique, et production de populations de crustacés amphipodes de la Manche occidentale. 1 Ampelisca typica (Bate). J. Exp. Mar. Biol. Ecol. 121: 1-22.

Dauvin, J.C. 1998d. Life cycle dynamics, and productivity of Crustacea-Amphipoda from the western English Channel. 4. Ampelisca armoricana Bellan-Santini et Dauvin. J. Exp. Mar. Biol. Ecol. 123: 235-252.

Edgar, G.J. 1990. The use of size structure of benthic macrofaunal communities to estimate faunal biomass and secondary production. J. Exp. Mar. Biol. Ecol. 137: 195-214.

Elizalde, M. 1994. Les communautés suprabenthiques bathyales de la marge sud du Canyon du Cap Ferret (golfe de Gascogne). Ph.D. thesis, Université de Bordeaux, No. 1123.

Fenton, G.E. 1996. Production and biomass of Tenagomysis tasmaniae Fenton, Anisomysis mixta australis (Zimmer) and Paramesopodopsis rufa Fenton from south-eastern Tasmania (Crustacea: Mysidacea). Hydrobiologia, 323: 23-30.

Fenwick, G.D. 1984. Life-history tactics of brooding Crustacea. J. Exp. Mar. Biol. Ecol. 84: 247-264.

Franz, D.R., and Tanacredi, J.T. 1992. Secondary production of the Amphipod Ampelisca abdita Mills and its importance in the diet of juvenile Winter Flounder (Pleuronectes americanus) in Jamaica Bay, New York. Estuaries, 15: 193-203.

Fredette, T.J., Diaz, R.J., Van Montfrans, J., and Orth, R.J. 1990. Secondary production within a seagrass bed (Zostera marina and Ruppia maritima) in lower Chesapeake Bay. Estuaries, 13: 431-440.

Gage, J.D. 1992. Benthic secondary production in the deep sea. In Deep-sea food chains and the global carbon cycle. Edited by G.T. Rowe and V. Pariente. Kluwer Academic Publishers, Dordrecht. pp. 183-198.
Hamilton, A.L. 1969. On estimating annual production. Limnol. Oceanogr. 14: 771-782.

Highsmith, R.C., and Coyle, K.O. 1990. High productivity of northern Bering Sea benthic amphipods. Nature (Lond.), 344: 862-864.

Huberdeau, L., and Brunel, P. 1982. Efficacité et selectivité faunistique de quatre appareils de prélèvements endo-, épi- et suprebenthiques sur deux types de fonds. Mar. Biol. 69: 331-343.

Hughes, R.G. 1978. Production and survivorship of epizoites of the hydroid Nemertesia antennina (L.). J. Mar. Biol. Assoc. U.K. 58: $333-345$.

Hynes-Hamilton, H.B.N., and Coleman, M. 1968. A simple method for assessing the annual production of stream benthos. Limnol. Oceanogr. 13: 569-573.

Kemp, P.F., Cole, F.A., and Swartz, R.C. 1985. Life history and productivity of the Phoxocephalid Rhepoxynius abronius (Barnard). J. Crustac. Biol. 5: 449-464.

Klein, G., Rachor, E., and Gerlach, S.A. 1975. Dynamics and production of two populations of the benthic tube-dwelling Amphipod Ampelisca brevicornis (Costa) in Helgoland Bight. Ophelia, 14: 139-159.

Kaïm-Malka, R.A. 1997. Biology and life cycle of Natatolana borealis Lilj. 1851, a scavenging isopod from the continental slope of the Mediterranean. Deep-Sea Res. Part I Oceanogr. Res. Pap. 44: 2045-2067.

Lindley, J.A. 1982. Population dynamics and production of Euphausiids: Meganyctiphanes norvegica and Nyctiphanes couchii in the North Atlantic Ocean and the North Sea. Mar. Biol. 66: $37-46$.

Mauchline, J. 1985. Growth and production of Euphausiacea (Crustacea) in the Rockall Trough. Mar. Biol. 90: 19-26

Mees, J., and Jones, M.B. 1997. The hyperbenthos. Ocean. Mar. Biol. Ann. Rev. 35: 221-255.

Mees, J., Abdulkerim, Z., and Hamerlynk, O. 1994. Life history, growth and production of Neomysis integer in the Westerschelde Estuary (S.W. Netherlands). Mar. Ecol. Prog. Ser. 109: 43-57.

Menzies, C.A. 1980. A note on the Hynes-Hamilton method of estimating secondary production. Limnol. Oceanogr. 25: 770-773.

Möller, P., and Rosenberg, R. 1982. Production and abundance of the amphipod Corophium volutator on the west coast of Sweden. Neth. J. Sea Res. 16: 127-140.

Morin, A., and Bourassa, N. 1992. Modèles empiriques de la production annuelle et du raport $P / B$ d'invertebrés benthiques d'eau courante. Can. J. Fish. Aquat. Sci. 49: 532-539.

Morin, A., Mousseau, T.A., and Roff, D.A. 1987. Accuracy and precision of secondary production estimates. Limnol. Oceanogr. 32: $1342-1352$.

Nelson, W.G. 1980. Reproductive patterns of gammaridean amphipods. Sarsia, 85: 61-71.

Olafsson, E.B., and Persson, L.E. 1986. Distribution, life cycle and demography in brackish water population of the isopod Cyathura carinata (Kroyer) (Crustacea). Estuar. Coast. Shelf Sci. 23: 673687.

Pauly, D., Christensen, V., Dalsgaard, J., Froese, R., and Torres, F., Jr. 1998. Fishing down marine food webs. Science (Washington, D.C.), 279: 860-863.

Plante, C., and Downing, J.A. 1989. Production of freshwater invertebrate populations in lakes. Can. J. Fish. Aquat. Sci. 46: 1489-1498.

Rachor, E., Arntz, W.E., Rumhor, H., and Mantau, K.H. 1982. Seasonal and long-term population fluctuations in Diastylis rathkei (Crustacea: Cumacea) of Kiel Bay and German Bight. Neth. J. Sea Res. 16: 141-150. 
Rainer, F., and Unsworth, P. 1991. Ecology and production of Nebalia spp. (Crustacea: Leptostraca) in a shallow-water seagrass community. Aust. J. Mar. Freshw. Res. 42: 53-68.

Robertson, A.I. 1979. The relationship between annual production: biomass ratios and lifespans for marine macrobenthos. Oecologia (Berl.), 38A: 193-202.

Sainte-Marie, B., and Brunel, P. 1985. Suprabenthic gradients of swimming activity by cold-water gammaridean amphipod Crustacea over a muddy shelf in the Gulf of Saint Lawrence. Mar. Ecol. Prog. Ser. 23: 57-89.

San Vicente, C., and Sorbe, J.C. 1993. Biologie du Mysidacé suprabenthique Schistomysis parkeri Norman, 1892 dans la zone sud du Golfe de Gascogne (plage d'Hendaye). Crustaceana (Leiden), 65: 222-252.

San Vicente, C., and Sorbe, J.C. 1995. Biology of the suprabenthic mysid Schistomysis spiritus (Norman, 1860) in the southeastern part of the Bay of Biscay. Sci. Mar. 59: 71-86.

Sarvala, J., and Uitto, A. 1991. Production of the benthic amphipods Pontoporeia affinis and $P$. femorata in a Baltic archipelago. Ophelia, 24: 71-90.

Sheader, M. 1977. Production and population dynamics of Ampelisca tenuicornis (Amphipoda) with notes on the biology of its parasite Sphaeronella longipes (Copepoda). J. Mar. Biol. Assoc. U.K. 57: 955-968.

Sorbe, J.C. 1981. Rôle du benthos dans le régime alimentaire des poissons démersaux du secteur sud Gascogne. Kieler Meeresforsch. Sonderh. 5: 479-489.
Sorbe, J.C. 1984. Contribution à la connaissance des peuplements suprabenthiques néritique sud-Gascogne Thèse d'état, Université de Bordeaux I.

Sudo, H., and Azeta, M. 1996. Life history and production of the amphipod Byblis japonicus Dahl (Gammaridea: Ampeliscidae) in a warm temperate zone habitat, Shijiki Bay, Japan. J. Exp. Mar. Biol. Ecol. 198: 203-222.

Tumbiolo M.A., and Downing, J.A. 1994. An empirical model for the prediction of secondary production in marine benthic invertebrate populations. Mar. Ecol. Prog. Ser. 114: 165-174.

Van Dolah, R.F., and Bird, E. 1980. A comparison of reproductive patterns in epifaunal and infaunal gammaridean amphipods. Estuar. Coast. Mar. Sci. 11: 593-604.

Vetter, E.W. 1996. Secondary production of a southern California Nebalia (Crustacea: Leptostraca). Mar. Ecol. Prog. Ser. 137: 95-101.

Waters, T.F. 1977. Secondary production in inland waters. Adv. Ecol. Res. 10: 91-164.

Wildish, D.J. 1984. Secondary production of four sublittoral, softsediment amphipod populations in the bay of Fundy. Can. J. Zool. 62: 1027-1033.

Wildish, D.J., and Peer, D. 1981. Methods for estimating secondary production in marine Amphipoda. Can. J. Fish. Aquat. Sci. 38: $1019-1026$.

Wooldridge, T.H. 1986. Distribution, population dynamics and estimates of production for the estuarine mysid Ropalophthalmus terratenalis. Estuar. Coast. Shelf Sci. 23: 205-223. 